\title{
QUEEN'S
UNIVERSITY
BELFAST
}

\section{PKB-mediated PHF20 phosphorylation on Ser291 is required for p53 function in DNA damage}

Li, Y., Park, J., Piao, L., Kong, G., Kim, Y., Park, K. A., Zhang, T., Hong, J., Hur, G. M., Seok, J. H., Choi, S-W., Yoo, B. C., Hemmings, B. A., Brazil, D., Kim, S-H., \& Park, J. (2013). PKB-mediated PHF20 phosphorylation on Ser291 is required for p53 function in DNA damage. Cellular Signalling, 25(1), 74-84. https://doi.org/10.1016/j.cellsig.2012.09.009

Published in:

Cellular Signalling

Document Version:

Peer reviewed version

Queen's University Belfast - Research Portal:

Link to publication record in Queen's University Belfast Research Portal

\section{Publisher rights}

This is the author's version of a work that was accepted for publication in Cellular Signalling. Changes resulting from the publishing process, such as peer review, editing, corrections, structural formatting, and other quality control mechanisms may not be reflected in this document. Changes may have been made to this work since it was submitted for publication. A definitive version was subsequently published in Cellular Signalling, VOL25, ISSUE1, 01/2013

\section{General rights}

Copyright for the publications made accessible via the Queen's University Belfast Research Portal is retained by the author(s) and / or other copyright owners and it is a condition of accessing these publications that users recognise and abide by the legal requirements associated with these rights.

Take down policy

The Research Portal is Queen's institutional repository that provides access to Queen's research output. Every effort has been made to ensure that content in the Research Portal does not infringe any person's rights, or applicable UK laws. If you discover content in the Research Portal that you believe breaches copyright or violates any law, please contact openaccess@qub.ac.uk. 


\section{Accepted Manuscript}

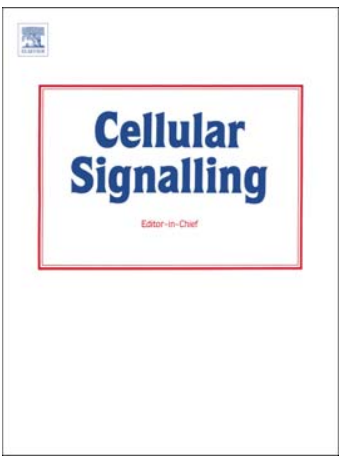

PKB-mediated PHF20 phosphorylation on Ser291 is required for p53 function in DNA damage

Yuwen Li, Jisoo Park, Longzhen Piao, Gyeyeong Kong, Yongbaek Kim, Kyeong Ah Park, Tiejun Zhang, Janghee Hong, Gang Min Hur, Jeong Ho Seok, Seung-Won Choi, Byong Chul Yoo, Brian A. Hemmings, Derek P. Brazil, Seon-Hwan Kim, Jongsun Park

PII: $\quad$ S0898-6568(12)00251-3

DOI: $\quad$ doi: $10.1016 /$ j.cellsig.2012.09.009

Reference: $\quad$ CLS 7677

To appear in: $\quad$ Cellular Signalling

Received date: 13 May 2012

Revised date: $\quad 20$ August 2012

Accepted date: $\quad 5$ September 2012

Please cite this article as: Yuwen Li, Jisoo Park, Longzhen Piao, Gyeyeong Kong, Yongbaek Kim, Kyeong Ah Park, Tiejun Zhang, Janghee Hong, Gang Min Hur, Jeong Ho Seok, Seung-Won Choi, Byong Chul Yoo, Brian A. Hemmings, Derek P. Brazil, Seon-Hwan Kim, Jongsun Park, PKB-mediated PHF20 phosphorylation on Ser291 is required for p53 function in DNA damage, Cellular Signalling (2012), doi: 10.1016/j.cellsig.2012.09.009

This is a PDF file of an unedited manuscript that has been accepted for publication. As a service to our customers we are providing this early version of the manuscript. The manuscript will undergo copyediting, typesetting, and review of the resulting proof before it is published in its final form. Please note that during the production process errors may be discovered which could affect the content, and all legal disclaimers that apply to the journal pertain. 


\section{PKB-mediated PHF20 phosphorylation on Ser291 is required for p53 function in DNA} damage.

Yuwen $\mathrm{Li}^{1, \#, \text { Jisoo Park }}{ }^{1, \#}$, Longzhen Piao ${ }^{1,2}$, Gyeyeong Kong ${ }^{1}$, Yongbaek Kim ${ }^{1}$, Kyeong Ah Park ${ }^{1}$, Tiejun Zhang ${ }^{1}$, Janghee Hong ${ }^{1}$, Gang Min Hur ${ }^{1}$, Jeong Ho Seok ${ }^{1}$, Seung-Won Choi $^{3}$, Byong Chul Yoo ${ }^{4}$, Brian A. Hemmings ${ }^{5}$, Derek P. Brazil ${ }^{6}$, Seon-Hwan Kim ${ }^{3, *}$ and Jongsun Park ${ }^{1, *}$

Department of ${ }^{1}$ Pharmacology, Metabolic Diseases and Cell Signaling Laboratory, Cancer Research Institute, Research Institute for Medical Sciences, College of Medicine, Chungnam National University, Daejeon, 301-131, South Korea, ${ }^{2}$ Department of Oncology, Affiliated Hospital of Yanbian University, Jilin, China, ${ }^{3}$ Department of Neurosurgery, College of Medicine, Chungnam National University, Daejeon, 301-131, South Korea, ${ }^{4}$ Research Institute and Hospital, National Cancer Center, Goyang, 410-769, South Korea, ${ }^{5}$ Friedrich Miescher Institute for Biomedical Research, Maulbeerstrasse 66, CH-4058 Basel, Switzerland, ${ }^{6}$ Centre for Vision and Vascular Science School of Medicine, Dentistry and Biomedical Sciences, Queen's University Belfast, BT12 6BA, Northern Ireland, UK.

* To whom all correspondence should be addressed; Dr. Jongsun Park, Tel: +82-42-580-8252, Fax: +82-42-585-6627, E-mail: insulin@cnu.ac.kr, and Dr. Seon-Hwan Kim, Tel: +82-42280-7368, E-mail: neons@cnu.ac.kr

\# These authors contributed equally to this work.

${ }^{\$}$ Current Address; Department of Pharmacy, Xijing Hospital, Fourth Military Medical University, Shaanxi, China

Combined word count for Introduction, Results and Discussion : 2746

Running Head: Regulation of PHF20 by PKB

Keywords : PHF20, Glioblastoma, PKB, p53, protein phosphorylation 


\section{Abstract}

PHD finger protein 20 (PHF20) is a transcription factor, which was originally identified in glioma patients. PHF20 appears to be a novel antigen in glioma, and has also termed gliomaexpressed antigen 2. PHF20 is thought to contribute to the development of cancers, including glioblastoma, lung cancer, colon cancer and ovarian cancer. However, little is known about the function of PHF20 in various cancers. Here we report that PHF20 contains two consensus sites for protein kinase $\mathrm{B}$ (PKB) phosphorylation (RxRxxS/T). PKB can directly phosphorylate PHF20 on Ser291 in vitro and in vivo. It has been shown that PKB participates in the tumor suppressor p53 regulated gene expression program and has a direct effect on p21 regulation after DNA damage. UV induced DNA damage result in accumulation of p53 and PKB activation. Interestingly, PKB-mediated PHF20 phosphorylation led to an inhibition of p53 induction following UV treatment, leading to the reduction of p21 transcriptional activity. Using anti PHF20 and anti pPKB (S473) antibodies, these events were mapped in various human cancer tissues. Taken together, these data suggest that PHF20 is a novel substrate for PKB and its phosphorylation by PKB plays an important role in tumorigenesis via regulating of p53 mediated signaling. 


\section{Introduction}

Plant homeodomain finger protein 20 (PHF20, also termed glioma-expressed antigen 2; GLEA2 and hepatocellular carcinoma associated antigen 58; HCA58), can elicit immune responses in glioblastoma patients and some controls [1, 2]. PHF20 shows the most frequent antibody response in glioma patients [2], and auto-antibodies against PHF20 significantly correlated with prolonged survival in patients with glioblastoma [3]. Paradoxically, lower survival was observed in non-small-cell lung carcinoma (NSCLC) patients with PHF20 [4]. In addition, PHF20 was identified as a homolog of hepatocellular carcinoma associated antigen 58 (HCA58) [5]. Interestingly PHF20 was prevalent in hepatocellular tumors of stage I. [4] and was also abundantly expressed in both advanced small-cell lung cancer and advanced adenocarcinoma, indicating that PHF20 might be tumor-associated antigen and could play a role in cancer progression. It has been reported that PHF20 works as a transcription factors and/or gene expression regulators [6]. Similar to PHF20, other members of PHD finger family are well documented as transcriptional regulators [7]. Notably, PHD finger family proteins (e.g., PHF1, PHF6, PHF3, PHF10 and PHF11) have been implicated in cancer and autoimmune diseases due to their transcriptional and immunogenic function on targeted proteins $[7-10,11]$.

Protein kinase $\mathrm{B}(\mathrm{PKB} / \mathrm{Akt})$ is activated by receptor tyrosine kinases and regulates a number of essential cellular processes, such as transcription, growth, proliferation, survival, and motility $[12,13]$. PKB activation occurs when PtdIns[3,4,5]P3 (a product of PI3K) binds to the pleckstrin homology $(\mathrm{PH})$ domain of PKB. Phosphorylation of two amino acids (Thr308 and Ser473) is then required for full PKB activation [14]. To date, over 50 proteins have been identified as putative PKB substrates, which contribute to a variety of cellular responses, including growth, metabolism and survival [15]. It has been suggested that PKB-mediated MDM2 phosphorylation promotes its nuclear translocation, leading to downregulation of p53 
and decreased p53 transcription $[16,17]$. Furthermore, $\mathrm{PKB} \alpha$ directly phosphorylates and inhibits p21, thereby blocking cell-cycle progression [18]. Recently PKB was shown to activate and phosphorylate transcription factor Twist-1, resulting in the inhibition of p53 induction in response to DNA damage in MCF-7 cells [19]. Consistent with previous studies, PKB activation in response to DNA insults promotes cell survival in vivo [12, 20, 21], clearly suggesting that PKB may be a major player in DNA damage response via p53 regulation.

PHF20 is a transcription factor located in the nucleus [6]. We have identified two putative phosphorylation motifs for PKB (RxRxxS/T), using Scansite software [22]. Previously PHF20 and PKB have not been described in the same signaling pathway. Here we show that PKB phosphorylates PHF20 on Ser291 both in vitro and in vivo. Overexpression of PHF20 in HCT116 cells caused the reduction of p53 accumulation and the inhibition of p53 transcriptional activity toward downstream target, p21 and Bax in response to DNA damage. UV-mediated cell death, monitored by FACS and cell cycle analysis, was enhanced in S291A expressed cells. Furthermore PHF20 overexpression was found in various cancer tissues compared to adjunct normal tissues. A high correlation between PHF20 expression and pPKB (Ser473) staining was observed in these cancers. Taken together, our data show that PHF20 is a novel PKB nuclear substrate and contributes to cancer development by controlling p53 tumor suppression via PKB mediated PHF20 phosphorylation. 


\section{Materials and Methods}

\subsection{Reagents}

Anti-phospho-Ser473 (PKB), anti-PKB, anti-phospho-Ser/Thr PKB substrate and anti-PHF20 antibody were purchased from Cell Signaling Technology. Anti-p53 (DO-1) and anti-actin antibodies were obtained from Santa Cruz Biotechnology. HRP conjugated anti-mouse, antirabbit IgG antibody, and LY294002 were from Calbiochem. $\lambda$-phosphatase was purchased from Biolabs. Insulin was from Roche. Recombinant $\mathrm{PKB} \alpha$ was purchased from Upstate. Doxorubicin was from sigma.

\subsection{Construction of expression vectors}

GFP-C-terminal tagged full length PHF20 (pEGEP-N1-PHF20) and pDs-Red-PHF20 were prepared by amplifying the cDNA library of HCT116 cells with primer 5' GAC CTC GAG ATG ACA AAG CAT CCA CCT AAC and 3' GAC GAA TTC G TGT TGA GCA GCA GAG GGC. GFP-N-terminal tagged full length PHF20 (ENTR-GFP-PHF20) and Flag tagged full length PHF20 (ENTR-Flag-PHF20) constructs were also prepared. Adenoviral expression vector for wild type PHF20 and LacZ was prepared by using Adenoviral Expression Kit (Invitrogen) according to the manufacturer. Adenoviruses were concentrated and purified using ultracentrifugation in a $\mathrm{CsCl}$ gradient as described previously [23, 24]. The deletion mutants of PHF20 were constructed in pGEX4T.1 expression vector by a standard PCR cloning strategy (pGEX4T.1-PHF20a, b, c and d). The mutants of PHF20 at Ser265 and Ser291 were created by using the QuickChangeTM site-directed mutagenesis kit (Stratagene) with pENTR-Flag-PHF20 WT as template. All constructs were amplified by PureHelixTM Fast-n-Pure Plasmid Kit (NanoHelix, South Korea) and confirmed by automated DNA sequencing. Sequences of the mutagenic oligonueotides are available upon request. $\mathrm{p} 21^{\text {waf }}$-luc reporter plasmid was kindly provided by Prof. Minho Song (Chungnam National University, 
South Korea) and Bax-luc reporter plasmid were obtained from Dr. Gongda Xue (Friedrich Miescher Institute, Switzerland).

\subsection{Cell culture and stimulation}

HEK293 and HCT116 cells were maintained in Dulbecco's modified Eagle's medium (DMEM) supplemented with $10 \%$ fetal bovine serum, $2 \mathrm{mM}$ glutamine, $100 \mathrm{unit} / \mathrm{ml}$ penicillin and $100 \mu \mathrm{g} / \mathrm{ml}$ streptomycin (Life Technologies). These cells were transfected by using jetPEI (Q-biogene) or FuGENE (Roche) reagent according to the manufacturer's instructions. The transfection mixture was removed after $24 \mathrm{hr}$ of incubation and cells were serum-starved for $24 \mathrm{hr}$ before stimulation with $20 \%$ fetal bovine serum for $1 \mathrm{hr}$. LY294002 inhibitor was pretreated for $30 \mathrm{~min}$ before stimulation as indicated. UV Cross-linker (BioLINK BLX, Vilber Lourmat) was used for UVC irradiation. HCT116 cells were irradiated with $50 \mathrm{mj}$ UVC at about $80 \%$ confluence with $2 \mathrm{ml}$ of medium in a $60-\mathrm{mm}$ Petri dish with the lid removed, and were further incubated for $4-8 \mathrm{~h}$. This approach was adapted from that as described previously [25].

\subsection{Expression of GST-fusion protein in bacterial system}

GST-tagged deletion mutants of PHF20 (PHF20 a, b, c and d) were purified from bacterial strain BL21DE3, transformed with GST-PHF20 expression constructs as described previously [26]. Briefly, bacteria were initially grown at $37{ }^{\circ} \mathrm{C}$ for $2 \mathrm{~h}\left(\mathrm{~A}_{600}=0.5-0.7\right)$ and subsequently induced with $0.5 \mathrm{mM}$ isopropyl-thio-D-galactopyranoside (Promega) for $6 \mathrm{~h}$ at $30{ }^{\circ} \mathrm{C}$.

\subsection{Immunoprecipitation and in vitro kinase assay}

HEK293 cells were placed on ice and extracted with lysis buffer containing $50 \mathrm{mM}$ Tris- $\mathrm{HCl}$, $\mathrm{pH} 7.5,1 \%$ (v/v) Nonidet P-40, $120 \mathrm{mM} \mathrm{NaCl}, 25 \mathrm{mM}$ sodium fluoride, $40 \mathrm{mM} \beta$-glycerol phosphate, $0.1 \mathrm{mM}$ sodium orthovanadate, $1 \mathrm{mM}$ phenylmethyl-sulfonyl fluoride, $1 \mathrm{mM}$ benzamidine and $2 \mu \mathrm{M}$ microcystin-LR. Flag-PHF20 was immunoprecipitated from $500 \mathrm{ug}$ 
of cell-free extracts with anti-Flag M2 agarose (sigma). The immune complexes were washed once with lysis buffer containing $0.5 \mathrm{M} \mathrm{NaCl}$, followed by lysis buffer and finally with kinase assay buffer containing $50 \mathrm{mM}$ Tris- $\mathrm{HCl}, \mathrm{pH} 7.5,0.1 \% \mathrm{v} / \mathrm{v}$ 2-mercaptoethanol. In vitro kinase assays with substrate peptides were performed for $30 \min$ at $30{ }^{\circ} \mathrm{C}$ in a $30 \mu 1$ reaction volume containing $100 \mathrm{ng}$ of the activated recombinant $\mathrm{PKB} \alpha, 1 \mathrm{mg} / \mathrm{ml}$ of substrate peptides (S265-tide; KRGRPPSIAPTAV, S265A-tide; KRGRPPAIAPTAV, S291-tide; LRRRKISKGCEVP, S291A-tide; LRRRKIAKGCEVP, Crosstide; GRPRTSSFAEG), $1 \mu \mathrm{M}$ protein kinase A inhibitor peptide (Alexis) and $50 \mu \mathrm{M}\left[\gamma^{-32} \mathrm{P}\right] \mathrm{ATP}$ (Amersham Biosciences; $1,000-2,000 \mathrm{cpm} / \mathrm{pmol}$ ) in kinase assay buffer. Reactions were stopped by adding EDTA to a final concentration of $50 \mathrm{mM}$ and processed as described previously [27]. For in vitro kinase

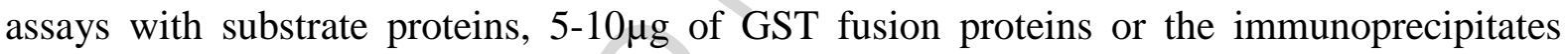
from $500 \mu \mathrm{g}$ of lysates were used. The reaction was stopped by adding SDS sample buffer and protein phosphorylation was analyzed by SDS-PAGE.

\subsection{Imaging analysis of cells}

HCT116 and U373MG cells were fixed in 4\% paraformaldehyde at room temperature (RT) for $10 \mathrm{~min}$, mounted with Fluoromount-G (Vector Laboratories) for $10 \mathrm{~min}$ and visualized using a OLYMPUS confocal microscope.

\subsection{Flow cytometry analysis}

After the proper treatment of cells, as described in the figure legends, cells were harvested and fixed in $70 \%$ ethanol overnight. Each sample was stained with $50 \mu \mathrm{g} / \mathrm{ml}$ propidium iodide (PI) in PBS and analyzed for the cell cycle by FL2 channels of a FACS Calibur flow cytometer (BD Biosciences), using emission filters of $532 \mathrm{~nm}$. At least 10,000 cells were analyzed in each of three independent experiments. For measurement of apoptotic or necrotic cell death, cells were stained with $10 \mu \mathrm{M}$ fluorescein isothiocyanate (FITC)-labeled annexin $\mathrm{V}$ and $\mathrm{PI}$, in a $\mathrm{Ca}^{2+}$-enriched binding buffer (10mM HEPES, pH7.4, 140mM NaCl, and 2.5 
$\mathrm{mM} \mathrm{CaCl} 2$ ), and analyzed by two-color flow cytometry. Annexin V and PI emissions were detected in the FL1 and FL2 channels of the FACS Calibur flow cytometer, using emission filters of 488 and $532 \mathrm{~nm}$, respectively. At least 10,000 cells were analyzed in each of three independent experiments.

\subsection{Luciferase reporter gene assays}

Cells were lysed in reporter lysis buffer containing $25 \mathrm{mM}$ Tris-phosphate, $2 \mathrm{mM}$ DTT, $2 \mathrm{mM}$ trans-1,2-cyclohexanediamine-N,N, $\mathrm{N}^{\prime}, \mathrm{N}^{\prime}$-tetraacetic acid, $10 \%(\mathrm{v} / \mathrm{v})$ glycerol and $1 \%(\mathrm{v} / \mathrm{v})$ Triton X-100. Luciferase activity was determined in a luminometer (Duo Lumat LB 9507) by incubating $20 \mu \mathrm{g}$ of cell lysate with luciferase assay substrate (Promega) and measuring light emission for $10 \mathrm{~s}$.

\subsection{Animal experiments}

All mice were acclimatized to a 12 -hour light/dark cycle at $22^{\circ} \mathrm{C} \pm 2{ }^{\circ} \mathrm{C}$ for 2 weeks with free access to food and water in a specific pathogen-free facility. $\operatorname{PKB} \beta(-/-)$ mice were described previously [28]. Eight-week-old male $\operatorname{PKB} \beta(+/+)$ mice and $\operatorname{PKB} \beta(-/-)$ mice were used. Fasting and refeeding were carried out as described in figure legends. All animal experiments were approved and performed by the Institutional Animal Use and Care Committee of the Friedrich Miescher Institute for Biomedical Research (FMI; Basel, Switzerland).

\subsection{Statistical analysis}

Quantification of Western blot analysis was carried out using the Tina version 2.1 program. Briefly, the relative intensity (area density) of bands of interest was quantitated by a densitometer. The background value from a blank band was subtracted. The results were calculated as the ratio change compared with the corresponding control bands. Data are presented as means \pm S.D. of the three independent experiments. The results were analyzed by Student's unpaired t-test (SPSS version 12.0 software, SPSS Inc.). p $<0.05$ (*) was 
considered significant, and $\mathrm{p}<0.01(* *)$ was highly significant compared with corresponding control values. 


\section{Results}

\subsection{PKB mediated phosphorylation of PHF20 in vitro at Ser265 and Ser291}

Using bioinformatics tools (Scansite motif; [22, 29]), we identified a PKB consensus substrate motif in human PHF20 (Fig. 1A; Ser265 and Ser291). Both phosphosites were conserved in mouse and bovine PHF20 (data not shown). In order to determine if PHF20 was a PKB substrate, synthetic peptides containing the potential PKB phosphorylation sites of PHF20 were tested in an in vitro PKB kinase assay. As shown in Fig. 1B, recombinant PKB $\alpha$ could phosphorylate these two peptides (S265-tide and S291-tide) as efficiently as Crosstide, which is derived from GSK-3 $\beta$ and the canonical PKB substrate peptide [30]. Substitution of serine to alanine in the corresponding peptide leads to complete loss of phosphorylation by PKB, indicating that Ser265 and Ser291 are the phospho-acceptor sites in these peptides (Fig. 1B). To further characterize PKB mediated phosphorylation of PHF20, a series of GST-fused deletion mutants of PHF20 were prepared (Fig. 1C, top panel). In vitro PKB kinase assays revealed that only PHF20-b fusion protein containing the Ser265 and Ser291 residues were phosphorylated by PKB (Fig. 1C, bottom panel). In addition, this phosphorylation event was also confirmed with anti-phospho(S/T)-PKB substrate antibody (Suppl. Fig. 1). These data were further supported by the dose-dependency on PHF20-b phosphorylation on increasing amounts of recombinant PKB (Fig. 1D). These data identify Ser265 and Ser291 as novel potential PKB phosphorylation sites in PHF20.

\subsection{Ser291 is a novel site for serum-induced phosphorylation of PHF20 in vivo.}

In order to evaluate PKB mediated phosphorylation of full-length PHF20, Flag-PHF20 was transiently transfected in HEK293 cells, immunoprecipitated and used as a substrate for invitro PKB kinase assay. Purified PKB $\alpha$ phosphorylated full-length PHF20 as efficiently as the GST-PHF20-b mutant (Fig. 2A), confirming PKB's ability to phosphorylate PHF20 as a 
full-length protein. The specificity of immunoprecipitation was confirmed by Western blot analysis with anti-PHF20 antibody (bottom panel, Fig. 2A). PHF20 phosphorylation was markedly enhanced by treating HEK293 cells with insulin or serum, with a concomitant increase in PKB activity (Fig. 2B). Serum-stimulated PHF20 phosphorylation was markedly inhibited by the pretreatment of cells with LY294002 (a PI3K inhibitor; Fig. 2C). Treatment of immunoprecipitated PHF20 with lambda phosphatase resulted in a marked reduction in PHF20 phosphorylation (Fig. 2C). These data suggest that PHF20 is a downstream of PI3K signaling in vivo and is reversibly phosphorylated. The novel PHF20 phosphorylation sites were then mutated and transfected into HEK293 cells. Serum stimulation induced phosphorylation of wild type PHF20 in starved HEK293 cells (Fig. 2D). This effect was completely abolished by in the S291A mutant while little or no change was detected in the S265A mutant (Fig. 2D). The double alanine mutant also showed no phosphorylation, indicating that Ser291 is the responsible residue for PHF20 phosphorylation induced by serum, most likely mediated by $\mathrm{PKB}$ in vivo. In order to further confirm that $\mathrm{PKB}$ is responsible for PHF20 phosphorylation, active or inactive forms of PKB were employed. In starvation condition, phosphorylation of PHF20 was not detectable in HEK293 cells (Fig. 2E, first lane). However overexpression of wild type (WT) or active form (CA) of PKB were able to markedly induce PHF20 phosphorylation while inactive form of PKB filed to induce PHF20 phosphorylation in serum-starved HEK293 cells (Fig. 2E). In addition, PHF20 phosphorylation was abolished during refeeding in the liver of PKB $\beta$ knockout mice compared to that of control mice (Figure 2F), strongly indicating that PHF20 is a physiological substrate for PKB in vivo.

\subsection{Overexpression of PHF20 promotes the destabilization of p53, leading to inhibition of p53 in response to DNA damage.}


PKB regulates p53 stability via phosphorylation of Mdm2, a ubiquitin ligase that regulates p53 levels in the nucleus [31]. Twist-1 phosphorylation is also required for PKB-mediated down-regulation of p53 in DNA damage condition [19]. Treatment of HCT116 cells with DNA-damaging reagent doxorubicin induced p53 accumulation, with a concomitant increase in Ser473 phosphorylation of PKB (Fig. 3A), consistent with previous studies [20, 32]. Doxorubicin-induced p53 accumulation was markedly attenuated in PHF20 overexpressing cells (Fig. 3A top panel). PHF20 phosphorylation was also elevated under these conditions and similar results were also detected in HeLa cells (Fig. 3B). Overexpression of PHF20 S291A mutant increased p53 accumulation in HCT116 cells following doxorubicin treatment (Fig. 3C). In contrast, no significant changes in p53 accumulation in S265A mutantexpressed cells, suggesting that PHF20 phosphorylation on Ser291 is required for PKBmediated p53 destabilization in DNA damage process (Fig. 3C). To further evaluate the effects of PHF20 on p53 function, the transcriptional activity of p53 downstream targets such as p21 and Bax were monitored using luciferase reporter plasmids. Doxorubicin treatment enhanced the p53 mediated p21 transcriptional activity at $6 \mathrm{~h}$ and $12 \mathrm{~h}$ time-points, which then decreased at $24 \mathrm{~h}$ (Fig. 3D left panel). Overexpression of PHF20 led to inhibition of p53 induced p21 transcriptional activity following doxorubicin treatment (Fig. 3D right panel). Similar results were obtained with a second p53 target, Bax (Fig. 3E). Overexpression of PHF20 S291A, but not S265A mutant recovered the p53 mediated p21 transcriptional activity (Fig. 3F). p53-driven Bax transcriptional activity was also regulated by PHF20 mutant in a similar manner (Fig. 3G). Taken together, these data suggest that PKB regulates p53 function by controlling PHF20 phosphorylation on S291 during DNA damage.

\subsection{Ser291 phosphorylation of PHF20 contributes to protection from UV-induced cell- death.}


Since PHF20 phosphorylation on Ser291 is required for PKB-mediated p53 destabilization in DNA damage process, the functional relevance of this process was evaluated by measuring the subG1 population of dead cells. Cell cycle analysis of PHF20 expressed cells revealed that the UV-induced subG1 population was markedly increased in PHF20 S291A mutant expressing cells compared to wild type (Fig. 4A; $17.9 \pm 1.1 \%$ for WT, $22.5 \pm 1.3 \%$ for S291A). Since DNA damage can induce cell death through p53-dependent or independent pathways $[33,34]$, the experiments were repeated in HCT116 cells lacking p53. Surprisingly these effects were absent in p53 (-/-) HCT116 cells (Fig. 4B), indicating that enhancement of doxorubicin-induced cell-death in S291A cells is a p53-dependent process. These results were further confirmed by irradiating the cell with UV and monitoring cell-death with propidium iodide (PI) and annexin $\mathrm{V}$ staining to distinguish the type of cell-death (ex; apoptosis and necrosis). FACS analysis with PI and annexin V staining showed that upregulation of subG1 population in S291A cells was due to elevation of apoptotic cells (PI positive and annexin V negative; Fig. 4C). This elevation of apoptotic cells in S291Aexpressed cells was abolished in p53 (-/-) cells (Fig. 4D), further confirming that p53 is required for the enhancement of UV-induced cell-death in PHF20 S291A cells.

\subsection{Overexpression of PHF20 correlates with Ser473 phosphorylation of PKB in human} cancer.

The expression level of PHF20 was examined in a range of human cancers. Immunohistochemical (IHC) analysis of tissue array with anti-PHF20 antibody revealed that the expression levels of PHF20 were markedly increased in different human cancers compared with normal tissue from cerebrum, colon, uterine cervix, ovary and esophagus (Fig. 5A). Remarkably, PHF20 was overexpressed in 14 out of 20 cerebrum cancer (70\%), 11 out of 15 uterine cervix cancer ( $75 \%)$ and 9 out of 18 colon cancer (50\%). The same human cancers 
were then stained with pPKB (Ser473) antibody to show the association of PKB activity with PHF20 (Fig. 5A and 5B). IHC analysis showed that PKB activation correlated highly with PHF20 overexpression, further supporting the phosphorylation of PHF20 by PKB as an important mediator of cancer development. 


\section{Discussion}

PHF20 has been identified as an immunologically recognized protein that may represent a novel candidate for cancer-specific immunotherapy [1-3]. Patients with malignant cancer may develop an autoimmune response as a consequence of generation of autoantibodies against various antigens, the clinical significance of which is not clear [35]. Initially, PHF20 was found to be an antigen causing a frequent immune response in the serum of $43 \%$ of glioblastoma patients [1]. Our data now identify that PHF20 is phosphorylated by PKB on Ser291 in vivo, and this phosphorylation functions to modulate PHF20-mediated p53 stability and cancer cell survivals.

Abnormal activation of PKB signaling is involved in a variety of human cancer including glioblastoma, lung and thyroid cancer [36-38]. Recently, structural changes in PHF20 has been proposed to be a potent inducer of non-small-cell lung cancer (NSCLC) promotion [4]. Consensus sites for PKB phosphorylation in PHF20 were identified using bioinformatics (Ser265 and Ser291, Fig. 1A). Synthetic peptides containing these sites as well as recombinant PHF20 fusion proteins were phosphorylated by PKB in in vitro kinase assays (Fig. 1A-1D). Expression of FLAG-PHF20 in HEK293 cells also underwent phosphorylation in response to constitutively active $\mathrm{PKB}$ expression or growth factor stimulation (Fig. 2A, 2B, and 2E). This effect was abolished by mutation of the Ser291, but not the Ser265 residue to Ala in PHF20, suggesting that Ser291 is the bona fide site for PKBmediated phosphorylation of PHF20 in cells (Fig. 2D). A role for PKB $\beta$ in the phosphorylation of PHF20 was suggested by the observation that PHF20 phosphorylation was undetectable in liver extracts from $\operatorname{PKB} \beta$ (-/-) mice compared to wild-type controls in response to feeding (Fig. 2F).

Many downstream targets of PKB are implicated in cancer progression, including the ubiquitin ligase Mdm2 that targets $\mathrm{p} 53$, as well as Twist1, a transcription factor that is 
involved in the DNA damage response in cancer [19, 31]. Given the previously identified role of PHF20 as an autoantigen in glioblastoma, phosphorylation of PHF20 by PKB may represent a novel regulatory mechanism in cancer. The dependence of PHF20 phosphorylation on $\mathrm{PKB} \beta$ isoform is consistent with recent data identifying $\mathrm{PKB}$ isoform specific substrates in different cells. For example, ankyrin repeat domain protein 2 (Ankrd2) has been identified as a $\mathrm{PKB} \beta$ substrate involved in myogenic differentiation in response to oxidative stress [39]. The actin-bundling protein palladin is also regulated by both $\mathrm{PKB} \alpha$ and $\mathrm{PKB} \beta$ in a non-redundant manner, with $\mathrm{PKB} \alpha$ phosphorylation of paladin regulating breast cancer cell migration, and $\mathrm{PKB} \beta$ phosphorylation regulating paladin transcription and protein stability [40]. Our data suggests that PHF20 may be specifically phosphorylated by PKB $\beta$ in liver, and suggests an isoform-specific regulation by upstream PKB proteins.

Our data demonstrated that PHF20 overexpression reduced the accumulation of p53 in response to the DNA damaging agent doxorubicin (Fig. 3A, B). A key role for PKB in this process was highlighted by the observation that expression of PHF20 S291A mutant, which could not be phosphorylated by PKB, enhanced p53 accumulation in HCT116 cells compared to wild type (Fig. 3C). In addition, PKB-mediated PHF20 phosphorylation on Ser291 was required for p53-mediated transcriptional repression of downstream targets p21 and Bax (Fig. 3D-3G). An accumulating body of data suggests that PKB plays an important role in regulating p53 function under DNA damage. Phosphorylation of the anti-apoptotic protein Twist-1 on Ser42 by PKB led to reduced p53 accumulation in response to DNA damage [19]. PKB mediated Mdm2 phosphorylation on Ser166 and Ser188 directly regulates p53 stability by stabilizing Mdm2 and increasing p53 targeting for proteosome-mediated ubiquitination [31]. PI3K/PKB signaling is critical for the inhibition of p53-dependent apoptosis [41]. Consistent with these results, UV-induced cell-death (monitored by sub-G1 population) was significantly enhanced in PHF20 S291A-expressed cells (Fig. 4A). Interestingly, this 
enhancement of UV-induced cell death was absent in p53 (-/-) cells, clearly indicating that p53 function is essential for these effects of PHF20 on UV-mediated cell-death (Fig. 4). PHF20 S291A-mediated enhancement of UV-induced cell death appeared to be apoptotic and again was p53-dependent (Fig. 4D). What is the mechanism by which PHF20 regulates cell death in a p53-dependent manner? Recent evidence suggests that the key function of histone modifications is to signal for recruitment or activity of effector molecules to DNA [42]. A Tudor domain in PHF20 has been identified, with PHF20 shown to act as a methyllysine binding protein during histone acetyltransferase protein complex formation [43]. These data suggest that PHF20 may be involved in the formation of p53-dependent transcriptional complexes bound to histones in response to DNA damage in cancer cells. Our new data strengthens the links between PKB and p53, and suggest that a signaling pathway from $\mathrm{PKB} \rightarrow \mathrm{PHF} 20 \rightarrow \mathrm{p} 53$ may be involved in histone-mediated transcriptional regulation and cell death.

PKB signaling pathway are frequently over-activated in human cancers either by changes in PKB isoform levels directly, or as a result of mutations in the PTEN lipid phosphatase, which result in increased activity of the kinase [13]. Levels of activated PKB were higher in malignant tumors from brain, colon and uterus (Fig. 5A). Consistently, PHF20 levels were also elevated in the same tumor region, correlated well with pSer473 phosphoantibody staining in tumor samples (Fig. 5B). These data suggest that upregulation of PHF20, possibly as a result of $\mathrm{PKB}$ phosphorylation may be a feature of cancer progression, with elevated levels of phospho-PHF20 inhibiting p53 mediated cell death, leading to enhanced cancer cell survival. Phospho-antibodies against Ser291 of PHF20 will be useful tools in monitoring the aggressiveness and progression of cancer in different tissues. Proof-ofprinciple in this regard emerged from data using phospho-antibodies reactive to the PKB phosphorylation site of Twist (Ser42). Elevated levels of pSer42 Twist phosphorylation were 
evident in human cancer, and were implicated in the regulation of p53-dependent cell survival [19]. Taken together, our data show that DNA-damage induced phosphorylation of PHF20 by PKB results in the destablization of p53, leading to inhibition of p53 target genes involved in cell survival. Therefore, cancer cells with high expression of PHF20 and elevated PKB activity could escape from p53-mediated cell cycle arrest and apoptosis, leading to tumour growth and metastasis (Fig. 5C). 


\section{Acknowledgements}

We would like to thank the following people for providing essential reagents; Dr. Minho Shong (Chungnam National University, South Korea) and Dr. Gongda Xue (Friedrich Miescher Institute, Switzerland) for valuable reagents. We also thank Ms. Debby Hynx (Friedrich Miescher Institute, Switzerland) for performing and collecting the liver samples from PKB $\beta$ (-/-) mice. This work was supported by the National Research Foundation of Korea (NRF) grant funded by the Korea Government (MEST) (No. 2012-0005767, No. 2012004714), by a grant from the National R\&D Program for Cancer Control funded by Ministry of Health \& Welfare, Republic of Korea. (No. 0720560) and by Chungnam National University Hospital Research Fund (2011). DPB is supported by funding from DEL Northern Ireland, Action Medical Research UK, BBSRC UK and Diabetes UK. 


\section{Figure legends}

Figure 1. Human PHF20 is phosphorylated by PKB in vitro (A) Schematic representation of the potential phosphorylation sites in human PHF20. The PKB phosphorylation sites of GSK3 $\beta$ (Ser9) and FOXO3 (Ser253 and Ser315) were shown together with the putative phosphorylation sites of PHF20 (Ser265 and Ser291). The consensus motif for PKB substrate is also indicated. (B) Recombinant $\mathrm{PKB} \alpha$ was used for in vitro kinase assay with the indicated peptides as described under "Experimental Procedures." The extent of phosphorylation of each peptide is expressed as a percentage relative to the Crosstide (GSK$3 \beta$ derived peptide; GRPRTSSFAEG). The phospho-acceptor is in boldface and residues mutated to Ala are underlined. The kinase activity is plotted as the average \pm S.D. of duplicate assays in three independent experiments. (C) Domain deletion mutants of PHF20 proteins (PHF20-a, -b, -c and -d) was produced and purified on glutathione-Sepharose beads from E. coli. In vitro kinase assay was performed with recombinant PKBain the presence of $\gamma\left[{ }^{32} \mathrm{P}\right]$-ATP. Kinase reactions were stopped and resolved by SDS-PAGE. Input of each GSTPHF20 proteins was also detected (bottom) (D) GST-PHF20-b was used in in-vitro kinase assay with different amount of PKB (20ng, 50ng and 100ng). MBP was used as positive control for PKB kinase. These results are representative of three independent experiments.

\section{Figure 2. Insulin or serum-induced phosphorylation of PHF20 on Ser291 is mediated by} PKBß in vivo (A) Flag-PHF20 was transiently transfected in HEK293 cells and was immunoprecipitated with anti-Flag antibodies. Immunoprecipitated PHF20 or GST-PHF20-b was incubated with recombinant $\mathrm{PKB} \alpha$ in vitro. Kinase reactions were analyzed by SDSPAGE. (B) Flag-PHF20 expressing HEK293 cells were starved for 24 h, followed by the stimulation with $100 \mathrm{nM}$ insulin for $15 \mathrm{~min}$, or $20 \%$ FBS for $1 \mathrm{~h}$. After immunoprecipitation (IP) with anti-Flag antibody, phosphorylated PHF20 was detected with anti-phospho-Ser/Thr 
PKB substrate antibody (top panel). Inputs are shown in the lower panels. The results are representative of three independent experiments. (C) Flag-PHF20 expressing HEK293 cells were pretreated with $50 \mu \mathrm{M}$ LY294002 for 15 min followed by the stimulation of cells with $20 \%$ serum for $1 \mathrm{~h}$. One set of immunoprecipitates were incubated with $\lambda$-phosphatase (400U) for $30 \mathrm{~min}$ and analyzed with the corresponding antibodies. Similar results were obtained in three separate experiments. (D) HEK293 cells were transiently transfected with wild type, S265A, S291A or S265A/S291A PHF20 and serum-stimulated. After immunoprecipitation (IP) with anti-Flag antibody, levels of phosphorylated PHF20 were analysed (top panel). These results are representative of three independent experiments. (E) HEK293 cells were transiently transfected with wild type PHF20 together with wild type (WT), active (CA) or inactive (KD) PKB. After immunoprecipitation (IP), phosphorylated forms of PHF20 were detected (top panel). The results are representative of three independent experiments. $(\mathrm{F})$ Immunoblot of hepatic PHF20 levels in PKB $\beta$ (-/-) mice and wild-type mice fasted for $6 \mathrm{~h}$, or fasted for $6 \mathrm{~h}$ and then refed for $2 \mathrm{~h}(\mathrm{n}=4-7)$. After immunoprecipitation (IP) with anti-PHF20 antibody, phosphorylated PHF20 was detected using anti-pSer/Thr antibody (top panel).

Figure 3. Ser291 Phosphorylation of PHF20 is important for the destabilization of p53 and the downregulation of p53 targets in DNA damage condition. (A) HCT116 or (B) HeLa cells were transiently transfected with pENTR-Flag-PHF20 for $24 \mathrm{~h}$, were treated with $5 \mu \mathrm{M}$ doxorubicin for the indicated time. Changes in the levels of $\mathrm{p} 53, \mathrm{PHF} 20$ and PKB were monitored with the indicated antibody (top panel). Phosphorylation of PHF20 and PKB Ser473 were also monitored (bottom panel). (C) Wild type (WT) or mutants (S265A and S291A) of PHF20 were expressed in HCT116 cells. Cells were treated with $5 \mu \mathrm{M}$ doxorubicin for the indicated time. Changes in protein levels and phosphorylation were monitored. The results are representative of three independent experiments. (D, E) HCT116 cells were 
cotransfected with $\mathrm{p} 21^{\text {waf }}$ - or Bax-luciferase reporter plasmids, with empty vector or FlagPHF20. Twenty four hours post-transfection, cells were treated with $5 \mu \mathrm{M}$ doxorubicin for the indicated time and luciferase reporter activity was measured. The results are mean \pm S.D. of three independent experiments. (F, G) HCT116 cells were co-transfected with $\mathrm{p} 21^{\text {waf }}$ - or Baxluciferase reporter plasmid and PHF20 wild type or mutants. Cells were treated with $5 \mu \mathrm{M}$ doxorubicin for the indicated time. Then luciferase reporter activity was measured. The results are mean \pm S.D. of three independent experiments. *, $\mathrm{p}<0.1, * *, \mathrm{p}<0.05, * * *, \mathrm{P}<0.01$.

Figure 4. Ser291 phosphorylation of PHF20 protects HCT116 cells from UV-induced cell-death in a p53 dependent manner (A) HCT116 p53 (+/+) cells or (B) HCT116 p53 (-/-) cells were transiently transfected with PHF20 wild type (WT) or non-phosphorylatable mutant (S291A). Twenty four hours posttransfection, cells were treated with UV (50mj) and analyzed by flow cytometry. Results are representative of three independent experiments (top panel). Each population of cells in the cell cycle (subG1, G1, S, G2-M phase) was plotted as mean \pm S.D. of three independent experiments (bottom pnael). *, p <0.1, **, p<0.05, ***, P<0.01. (C) HCT116 p53 (+/+) cells or (D) HCT116 p53 (-/-) cells were transiently transfected with PHF20 wild type (WT) or non-phosphorylatable mutant (S291A). The cells were labeled with annexin $\mathrm{V}$ and propidium iodide (PI) to distinguish the type of cell death. The population of apoptotic cell (PI positive and annexin V negative) was calculated. These results are representative of three independent experiments (top panel). The results were plotted as mean percentage cell death \pm S.D. of three independent experiments (bottom panel). $*, \mathrm{p}<0.1, * *, \mathrm{p}<0.05, * * *, \mathrm{P}<0.01$.

Figure 5. PHF20 expression and phospho-PKB Ser473 levels in human malignancy (A) Human multiple tissue arrays were analyzed by immunohistochemistry (IHC) for PHF20 and 
phospho-PKB Ser473 staining. Images show representative cores from cerebrum, colon and uterine cervix. Scale bars, $100 \mu \mathrm{m}$. (B) Various tissues samples were analyzed by IHC with PHF20 and phospho-PKB (Ser473) antibody. The results were calculated as positive percentage of total sample numbers counted. Only patient samples present in both tumor arrays and stained with two antibodies were used for the analysis. (C) Schematic illustration of the working model for the action of $\mathrm{PKB} / \mathrm{PHF} 20$ in cancer. DNA-damage induced phosphorylation of PHF20 by PKB results in the destablization of p53, leading to inhibit p53 target gene, p21 and Bax. Therefore, cancer cells with high expression of PHF20 with the elevated PKB activity may escape from p53-mediated cell cycle arrest and apoptosis. 


\section{References}

[1] Fischer U, Struss AK, Hemmer D, Pallasch CP, Steudel WI, Meese E, Clin Exp Immunol. 2001;126:206-213.

[2] Heisel SM, Ketter R, Keller A, Klein V, Pallasch CP, Lenhof HP, Meese E, PLoS One. 2008;3:e2164.

[3] Pallasch CP, Struss AK, Munnia A, Konig J, Steudel WI, Fischer U, Meese E, Int J Cancer. 2005;117:456-459.

[4] Bankovic J, Stojsic J, Jovanovic D, Andjelkovic T, Milinkovic V, Ruzdijic S, Tanic N, Lung Cancer. 2010;67:151-159.

[5] Wang Y, Han KJ, Pang XW, Vaughan HA, Qu W, Dong XY, Peng JR, Zhao HT, Rui JA, Leng XS, Cebon J, Burgess AW, Chen WF, J Immunol. 2002;169:1102-1109.

[6] Taniwaki M, Daigo Y, Ishikawa N, Takano A, Tsunoda T, Yasui W, Inai K, Kohno N, Nakamura Y, Int J Oncol. 2006;29:567-575.

[7] Wei M, Liu B, Su L, Li J, Zhang J, Yu Y, Yan M, Yang Z, Chen X, Liu J, Lv X, Nie H, Zhang Q, Zheng Z, Yu B, Ji J, Zhang J, Zhu Z, Gu Q, Molecular cancer therapeutics. 2010;9:1764-1774.

[8] Baker LA, Allis CD, Wang GG, Mutation research. 2008;647:3-12.

[9] Struss AK, Romeike BF, Munnia A, Nastainczyk W, Steudel WI, Konig J, Ohgaki H, Feiden W, Fischer U, Meese E, Oncogene. 2001;20:4107-4114.

[10] Yoo AS, Staahl BT, Chen L, Crabtree GR, Nature. 2009;460:642-646.

[11] Rahman N, Stewart G, Jones G, Immunology and cell biology. 2010;88:817-824.

[12] Bozulic L, Hemmings BA, Curr Opin Cell Biol. 2009;21:256-261.

[13] Fayard E, Xue G, Parcellier A, Bozulic L, Hemmings BA, Curr Top Microbiol Immunol. 2011;346:31-56. 
[14] Cameron AJ, De Rycker M, Calleja V, Alcor D, Kjaer S, Kostelecky B, Saurin A, Faisal A, Laguerre M, Hemmings BA, McDonald N, Larijani B, Parker PJ, Biochem Soc Trans. 2007;35:1013-1017.

[15] Manning BD, Cantley LC, Cell. 2007;129:1261-1274.

[16] Mayo LD, Donner DB, Proc Natl Acad Sci U S A. 2001;98:11598-11603.

[17] Zhou BP, Liao Y, Xia W, Spohn B, Lee MH, Hung MC, Nat Cell Biol. 2001;3:245-252.

[18] Heron-Milhavet L, Franckhauser C, Rana V, Berthenet C, Fisher D, Hemmings BA, Fernandez A, Lamb NJ, Mol Cell Biol. 2006;26:8267-8280.

[19] Vichalkovski A, Gresko E, Hess D, Restuccia DF, Hemmings BA, Oncogene. 2010;29:3554-3565.

[20] Bozulic L, Surucu B, Hynx D, Hemmings BA, Mol Cell. 2008;30:203-213.

[21] Park J, Feng J, Li Y, Hammarsten O, Brazil DP, Hemmings BA, The Journal of biological chemistry. 2009;284:6169-6174.

[22] Yaffe MB, Leparc GG, Lai J, Obata T, Volinia S, Cantley LC, Nat Biotechnol. 2001;19:348-353.

[23] Lieber A, He CY, Kirillova I, Kay MA, J Virol. 1996;70:8944-8960.

[24] Piao L, Li Y, Kim SJ, Byun HS, Huang SM, Hwang SK, Yang KJ, Park KA, Won M, Hong J, Hur GM, Seok JH, Shong M, Cho MH, Brazil DP, Hemmings BA, Park J, Cancer Res. 2009;69:3397-3404.

[25] Bendjennat M, Boulaire J, Jascur T, Brickner H, Barbier V, Sarasin A, Fotedar A, Fotedar R, Cell. 2003;114:599-610.

[26] Yang KJ, Shin S, Piao L, Shin E, Li Y, Park KA, Byun HS, Won M, Hong J, Kweon GR, Hur GM, Seok JH, Chun T, Brazil DP, Hemmings BA, Park J, J Biol Chem. 2008;283:14801491. 
[27] Seok JH, Park KA, Byun HS, Won M, Shin S, Choi BL, Lee H, Kim YR, Hong JH, Park J, Hur GM, Korean J Physiol Pharmacol. 2008;12:185-191.

[28] Dummler B, Tschopp O, Hynx D, Yang ZZ, Dirnhofer S, Hemmings BA, Molecular and cellular biology. 2006;26:8042-8051.

[29] Camacho C, Coulouris G, Avagyan V, Ma N, Papadopoulos J, Bealer K, Madden TL, BMC Bioinformatics. 2009;10:421.

[30] Cross DA, Alessi DR, Cohen P, Andjelkovich M, Hemmings BA, Nature. 1995;378:785-789.

[31] Feng J, Tamaskovic R, Yang Z, Brazil DP, Merlo A, Hess D, Hemmings BA, J Biol Chem. 2004;279:35510-35517.

[32] Surucu B, Bozulic L, Hynx D, Parcellier A, Hemmings BA, The Journal of biological chemistry. 2008;283:30025-30033.

[33] Zong WX, Ditsworth D, Bauer DE, Wang ZQ, Thompson CB, Genes Dev. 2004; $18: 1272-1282$.

[34] Gudkov AV, Komarova EA, Nat Rev Cancer. 2003;3:117-129.

[35] Abu-Shakra M, Buskila D, Ehrenfeld M, Conrad K, Shoenfeld Y, Ann Rheum Dis. 2001;60:433-441.

[36] Ermoian RP, Kaprealian T, Lamborn KR, Yang X, Jelluma N, Arvold ND, Zeidman R, Berger MS, Stokoe D, Haas-Kogan DA, Journal of neuro-oncology. 2009;91:19-26.

[37] Xu CX, Jin H, Shin JY, Kim JE, Cho MH, Frontiers in bioscience (Elite edition). 2010;2:1472-1484.

[38] Kada F, Saji M, Ringel MD, Current drug targets. Immune, endocrine and metabolic disorders. 2004;4:181-185.

[39] Cenni V, Bavelloni A, Beretti F, Tagliavini F, Manzoli L, Lattanzi G, Maraldi NM, Cocco L, Marmiroli S, Molecular biology of the cell. 2011;22:2946-2956. 
[40] Chin YR, Toker A, Cell Adh Migr. 2011;5:211-214.

[41] Gottlieb TM, Leal JF, Seger R, Taya Y, Oren M, Oncogene. 2002;21:1299-1303.

[42] Yun M, Wu J, Workman JL, Li B, Cell research. 2011;21:564-578.

[43] Badeaux AI, Yang Y, Cardenas K, Vemulapalli V, Chen K, Kusewitt D, Richie E, Li W, Bedford MT, J Biol Chem. 2011. 
Fig.1 Li et. al.

A

\begin{tabular}{|c|c|c|}
\hline PHF20 & $\left.\right|_{\text {Ser291 }} ^{\text {Ser265 }}$ & $\begin{array}{l}\mathrm{KR} G R P P S I A P T A V \\
\text { IRRRKISKGCEVP }\end{array}$ \\
\hline GSK- $3 \beta$ & Ser9 & GRPRTTSFAESC \\
\hline FOXO3 & $\left.\right|_{\text {Ser315 }} ^{\text {Ser253 }}$ & $\begin{array}{l}\text { PRRRAVSMDNS1 } \\
\text { FR } R \text { RTNSNAST }\end{array}$ \\
\hline$P K$ & & $\underline{R} \times \underline{R} \times x S / T$ \\
\hline
\end{tabular}

B

PKB

Relative PKB activity

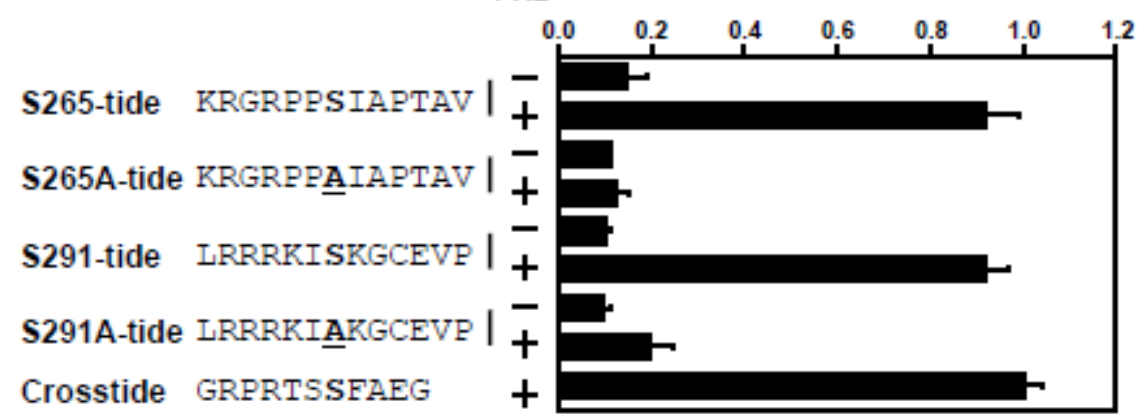


Fig. 1 Li et. al.

\section{C}

D

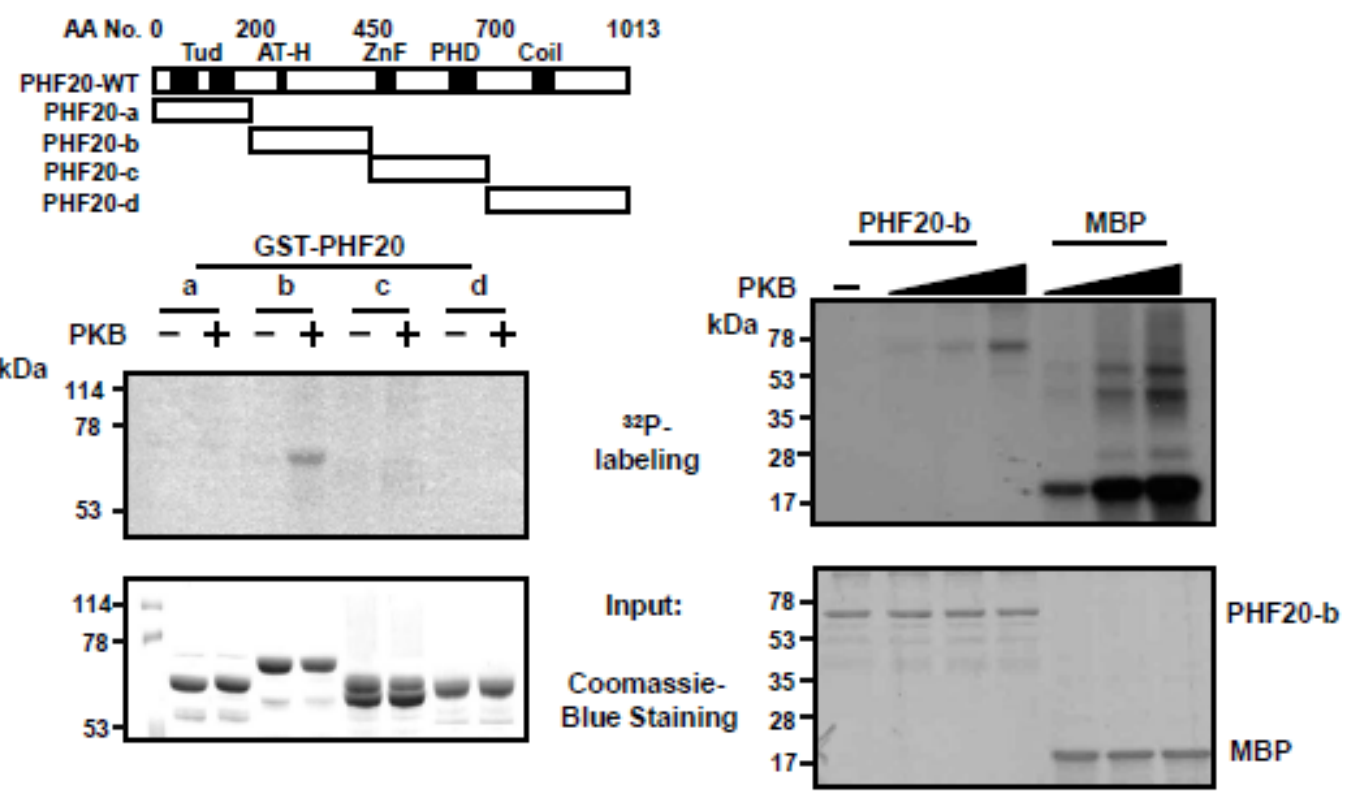


Fig. 2 Li et. al.

A

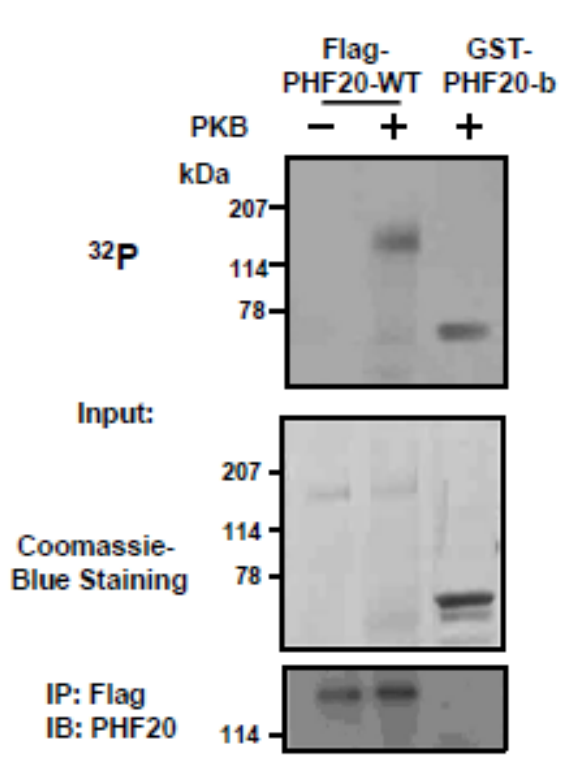

B

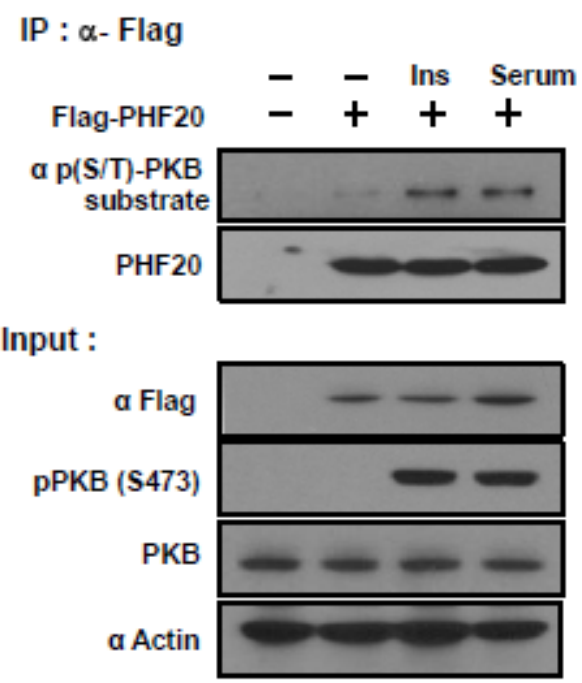


Fig. 2 Li et. al.

C

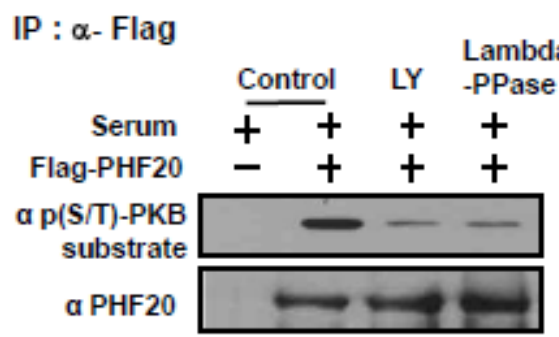

Input :

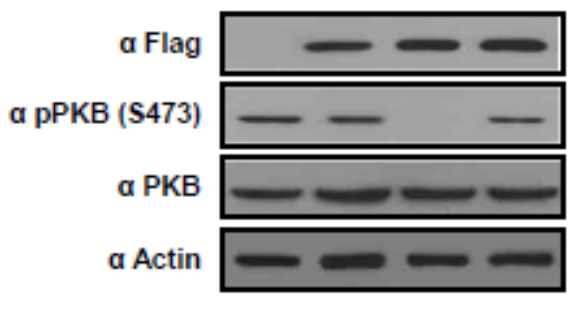

D

IP : $\alpha$ - Flag

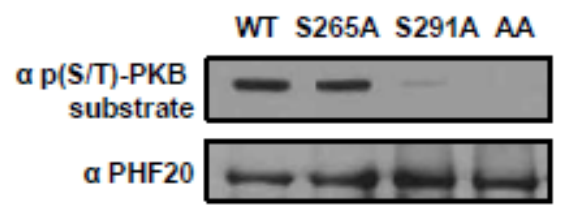

Input :

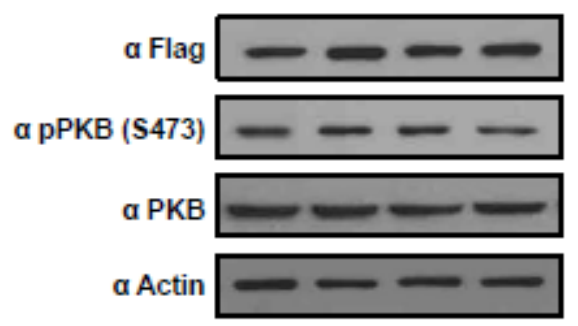


Fig. 2 Li et. al.

E

IP: $\alpha$-Flag

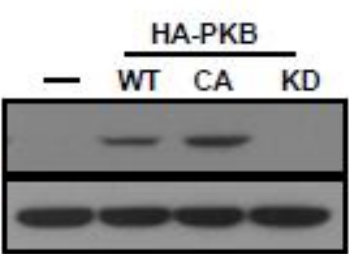

Input :

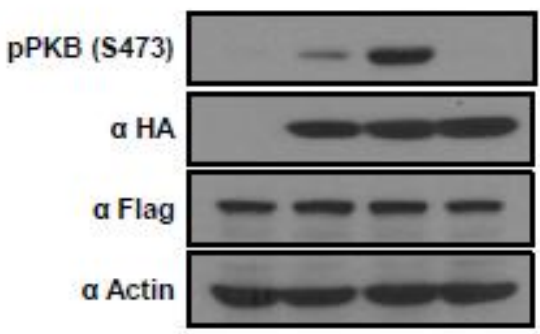


Fig. 2 Li et. al.

F

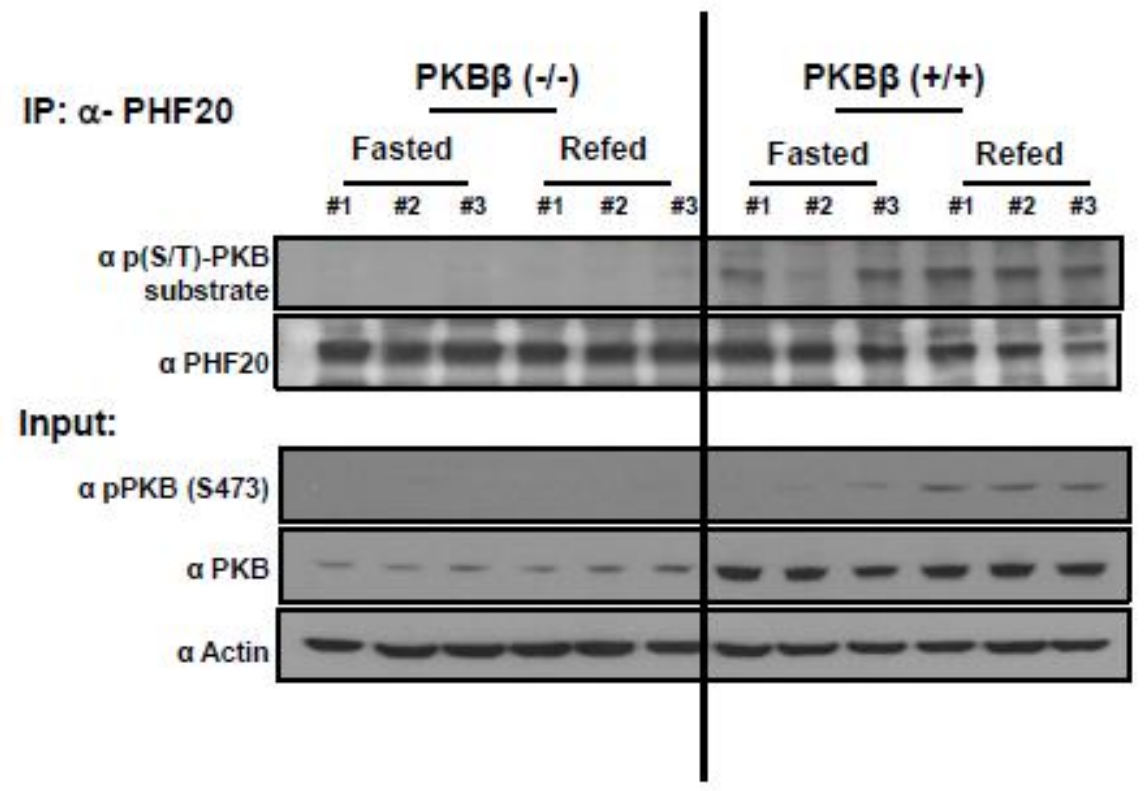


Fig. 3 Li et. al.

A

B

\section{HCT116}

\section{HeLa}

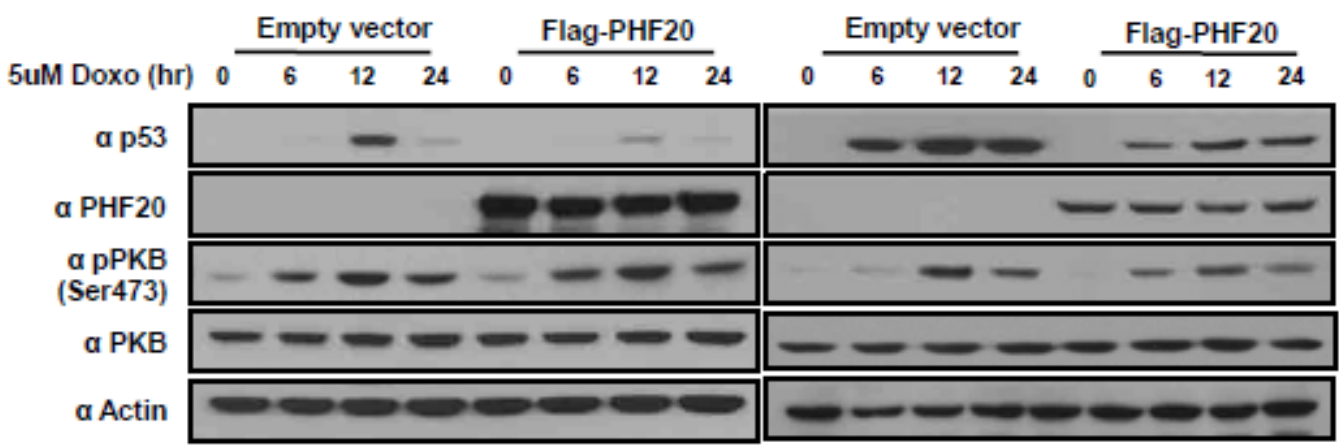

IP: $\alpha$-Flag

a p(S/T)-PKB

a PHF20

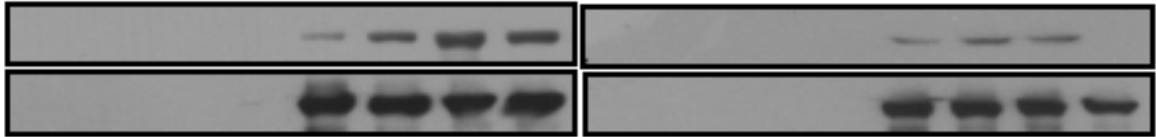


Fig. 3 Li et. al.

C

\begin{tabular}{|c|c|c|c|c|c|c|c|c|c|c|c|}
\hline PHF20 & \multicolumn{4}{|c|}{ WT } & \multicolumn{4}{|c|}{ S265A } & \multicolumn{3}{|c|}{ S291A } \\
\hline 5uM Doxo (hr) & 0 & 6 & 12 & 24 & 0 & 6 & 12 & 24 & 0 & 6 & 24 \\
\hline a p 53 & & $=$ & - & - & & - & - & - & & $=$ & $=-$ \\
\hline a PHF20 & & & $=$ & 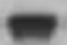 & & 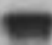 & 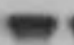 & $=$ & $\mathbf{m e} x-1$ & $=0$ & $=$ \\
\hline a pPKB (Ser473) & & te- & - & - & & - & - & - & & -- & $=-$ \\
\hline$\alpha$ PKB & - & 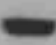 & - & - & - & $=$ & -1 & $=1$ & Ba & $-=$ & $-\infty$ \\
\hline a A & & & & & & & & & & & \\
\hline
\end{tabular}

IP: $\alpha$-Flag

$\begin{array}{r}\alpha \text { p(S/T)-PKB } \\ \text { substrate }\end{array}$
a PHF20 
Fig. 3 Li et. al.

D

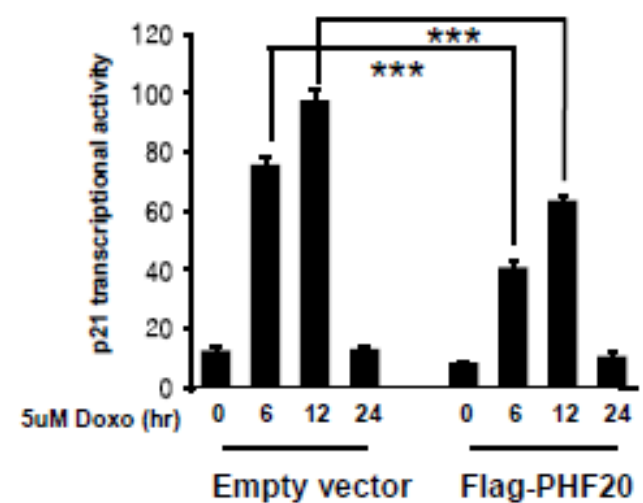

E

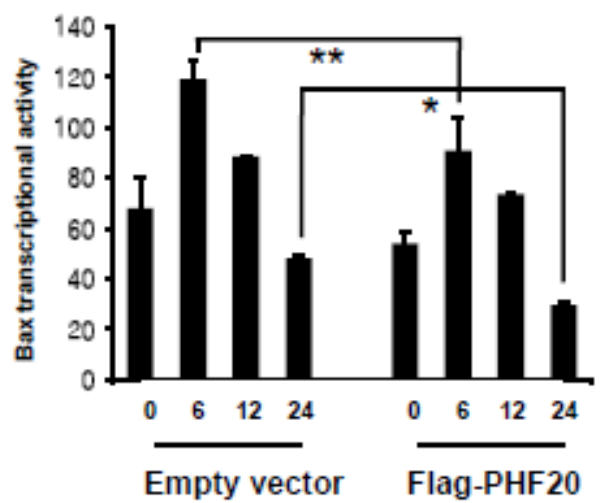


F

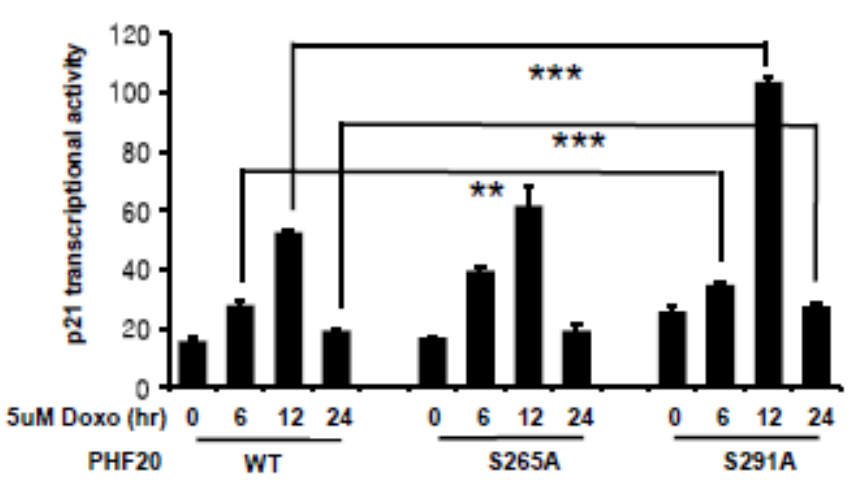

Fig. 3 Li et. al.

G

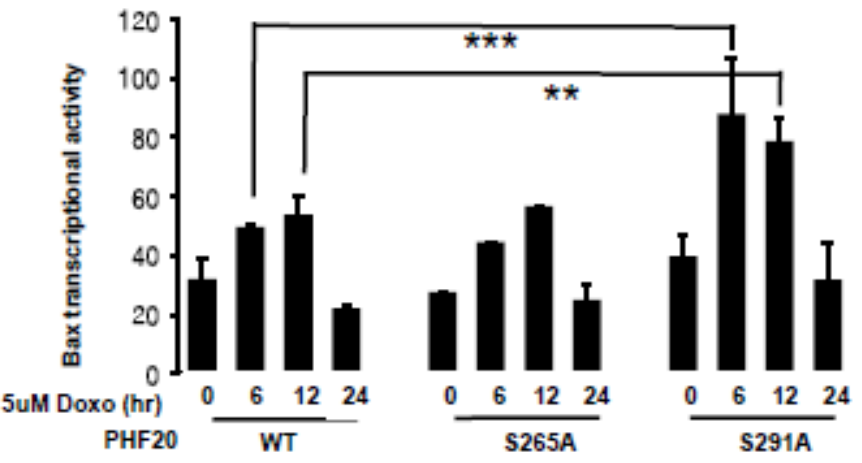


Fig. 4 Li et. al.

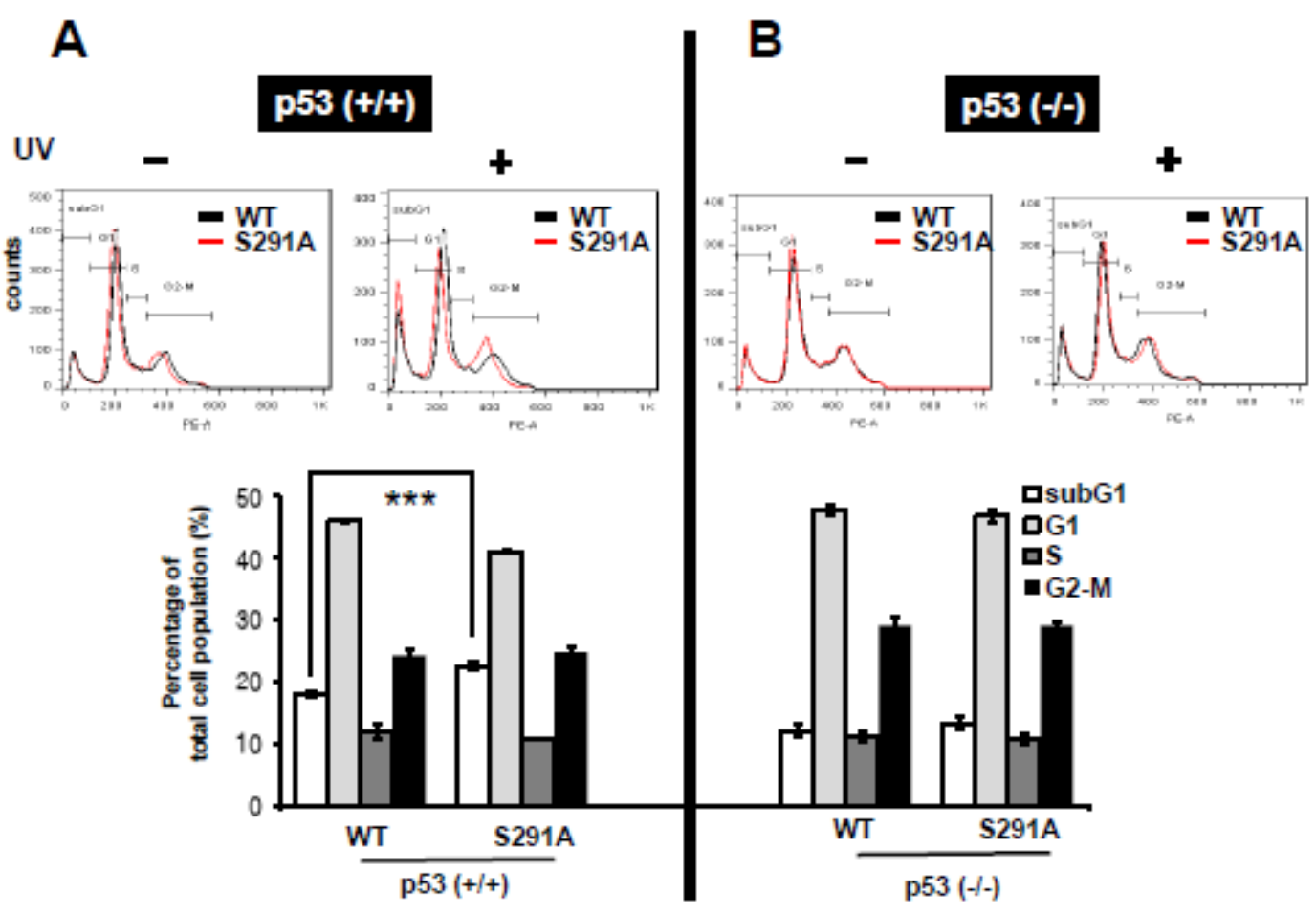


Fig. 4 Li et. al.

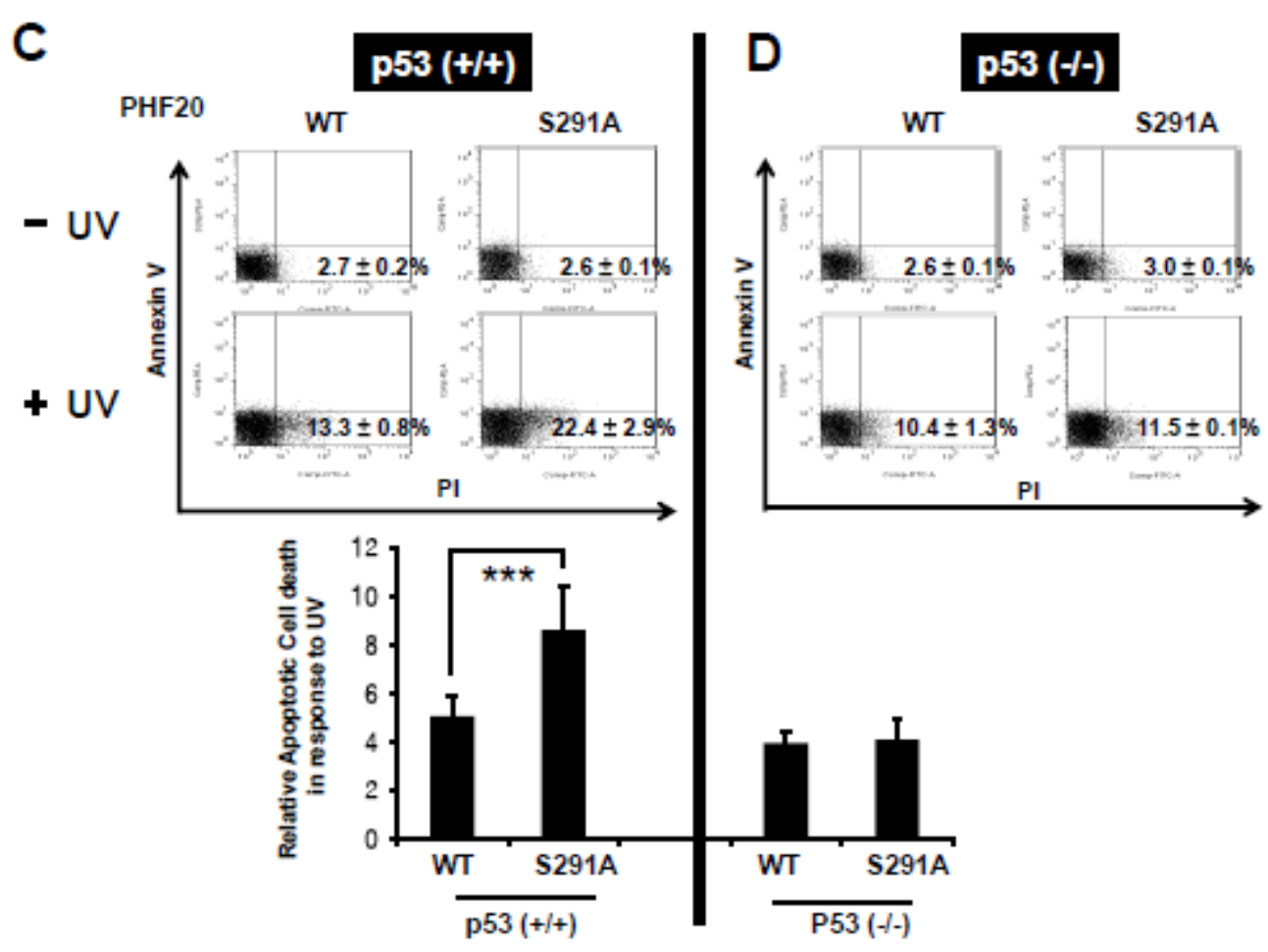


Fig. 5 Li et. al.

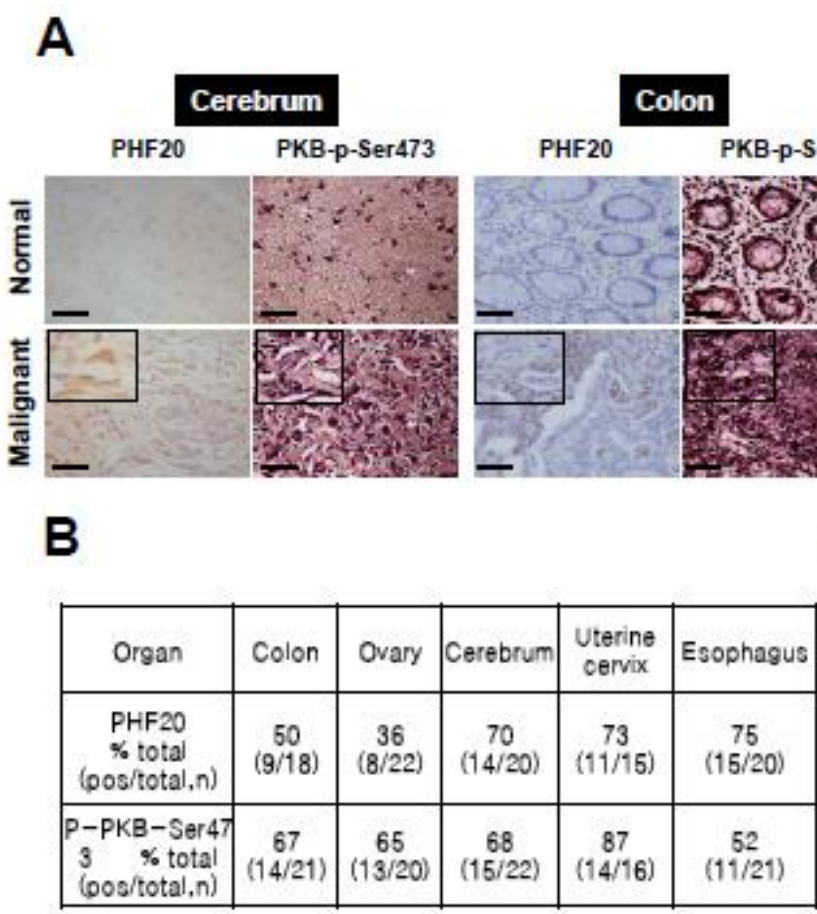

C DNA damage

Uterine cervix
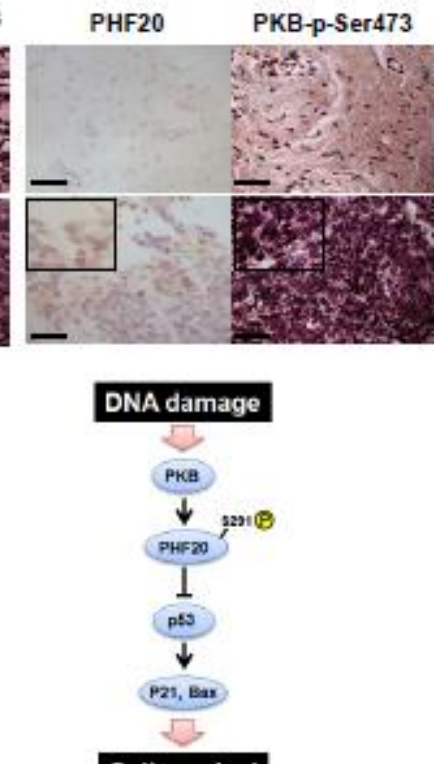

Cell survival 


\section{Highlights}

- PHD finger protein 20 (PHF20) is a firstly identified in glioma patients.

- PKB can directly phosphorylate PHF20 on Ser291 in vitro and in vivo.

- PHF20 phosphorylation by PKB led to an inhibition of p53 induction following UV treatment

- Expression of PHF20 and PKB activity is correlated in various human cancer tissues.

- PHF20 is a novel substrate for PKB and could be an important target for glioma patients. 